\title{
Diádikus stressz és megküzdés - elméleti modellek és alkalmazások
}

\author{
MARTOS JÚLIA ${ }^{1 *}$ - SALLAY VIOLA ${ }^{1}$ - SZABÓ EVELIN² - \\ TÓTH-VAJNA RITA² - MARTOS TAMÁS ${ }^{1}$ \\ ${ }^{1}$ Szegedi Tudományegyetem, Bölcsészettudományi Kar, Pszichológiai Intézet, Szeged \\ ${ }^{2}$ Semmelweis Egyetem, Doktori Iskola, Budapest \\ (Beérkezett: 2017. július 5., elfogadva: 2017. december 4.)
}

\begin{abstract}
A stresszel való egyéni megküzdés modelljei mellett mind elméleti, mind gyakorlati szempontból egyre inkább előtérbe kerülnek a megküzdés társas folyamatai. Elméleti összefoglalónkban ezért bemutatjuk a párkapcsolati stressz és megküzdés leírására létrejött különböző modelleket, ezek között a Kapcsolatfókuszú Megküzdési Modellt; a RendszerTranzakciós Modellt; a Fejlődési-Kontextuális Megküzdési Modellt; valamint a Kapcsolati Intimitás Modellt. Az egyes elméleteket annak alapján hasonlítjuk össze, hogy milyen típusú kapcsolati stresszfajtákat integrálnak a modellben, illetve összevetjük az elméletek által leírt különböző megküzdési stratégiákat. Ismertetjük továbbá a diádikus megküzdés empirikus vizsgálatára létrehozott kérdőíves mérőeszközöket és kutatási elrendezéseket, valamint bemutatjuk az egyes elméletek alapján létrehozott gyakorlati, terápiás lehetőségeket is. Összességében megállapíthatjuk, hogy a páros stressz és megküzdés bemutatott modelljei egyrészt jól értelmezhetők a kapcsolati tudomány (relationship science) tágabb elméleti keretében, másrészt megfelelő alapot adnak a gyakorlati alkalmazás számára is.
\end{abstract}

Kulcsszavak: diádikus megküzdés, diádikus stressz, Fejlődési-Kontextuális Megküzdési Modell, Kapcsolatfókuszú Megküzdési Modell, Kapcsolati Intimitás Modell, RendszerTranzakciós Modell

\section{Bevezetés}

A stressz fogalma a mindennapi szóhasználat részévé vált. „Stresszes napom volt”, ,túlstresszelem a dolgot”, „nagy a munkahelyi stressz”, etc. A stressz jelenségének elismerésével együtt azonban mind a köznyelv, mind pedig a szakmai gondolkodás elsősorban az egyéni problémák és megoldáskeresések területére „utalja”. A tudományos elméletalkotásban ugyanakkor egyre jelentősebb munka folyik a kapcsolati folyamatok és a stresszel kapcsolatos jelenségek közötti összefüggések feltárása céljából.

\footnotetext{
* Levelező szerző: Martos Júlia, SZTE Pszichológiai Intézet, 6722 Szeged, Egyetem u. 1. E-mail: martosjulia94@gmail.com
} 
A Current Opinion in Psychology címú folyóirat, amely egyes területek úttöró gondolatait gyújti össze, például a 2017/1. számát a kapcsolatok és stressz témájának szentelte (pl. Farrell \& Simpson, 2017; Karantzas, Simpson, \& McCabe, 2017; Slatcher \& Schoebi, 2017). Ennek a fejlődésnek az egyik megjelenése a páros megküzdés kutatása, amely már hazánkban is elindult (vö. Martos, Sallay, Nistor, \& Józsa, 2012). Tanulmányunkban ezért áttekintjük a páros megküzdés különféle modelljeit és az ezekre alapozható intervenciós lehetőségeket.

\subsection{Stressz és megküzdés - a fogalompár történetének rövid áttekintése}

A pszichológiai értelemben vett stresszfogalom tudományos meghatározását kezdetektől fogva sok vita övezi. A klasszikus kognitív-viselkedéselméleti hagyományok, amelyek az S-R (stimulus-reaction) megközelítésen alapulnak, a stressz fogalmát is ingerként vagy reakcióként határozták meg (Lazarus \& Folkman, 1984). A reakcióként való megközelítés a stresszt a test egy eseményre adott nonspecifikus reakciójaként definiálja, és három fázisát írja le (vészreakció, ellenállás és kimerülés; Selye, 1976). McEwen (1998), aki szintén a biológiai mechanizmusok figyelembevételével vizsgálja a stresszválaszokat, az alapján tesz köztük megkülönböztetést, hogy azok hosszútávon okoznak-e a szervezetben patofiziológiás változásokat („Allosztázis modell” - lásd McEwen, 1998, 2007; McEwen \& Seeman, 1999).

Ha stresszt ingernek, tehát külső, avagy környezeti hatásnak tekintjük, ezeket az ingereket különbözó típusokba sorolhatjuk. Lazarus és Cohen (1977) három típust különböztetnek meg: (1) a sok embert egyszerre érintő, nagymértékú hatásokat (mint például természeti katasztrófák), (2) nagymértékú hatásokat, amelyek azonban csak néhány, vagy egy embert érintenek (mint például egy családtag halála), (3) hétköznapi problémákat, boszszúságokat. Egy másik megközelítés az inger hatásának nagysága és kiterjedése helyett a hatás időtartama alapján különíti el a stresszorok négy típusát. Ezek között szerepelnek (1) az akut, rövid időtartamú stresszorok (mint egy mútétre való várakozás), (2) a stresszor-sorozatok (mint például egy munkahely elvesztése következtében létrejövő hatások), (3) a krónikus, időszakos stresszorok (mint például konfliktussal terhelt családi látogatások), illetve (4) a krónikus stresszorok (például hosszantartó vagy gyógyíthatatlan betegségek) (Elliott \& Eisdorfer, 1982). Egy újabb tanulmányban Randall és Bodenmann (2009) egy differenciáltabb tipológiát ír le, amely a stresszorokat három dimenzió mentén csoportosítja: (1) kívülról vagy belülről érkező stresszorok, (2) major (nagy hatású) vagy minor (mindennapi) stresszorok, illetve (3) akut vagy krónikus stresszorok. 
A hagyományos inger-válasz megközelítésen túllépve alkotta meg a tranzakcionális stressz-modellt Lazarus és Folkman (1984), amely a legszélesebb körben ismert és legtöbbet hivatkozott pszichológiai stresszelméletnek mondható. Ők a pszichológiai stressz fogalmát sajátos kapcsolatnak nevezik az egyén és a környezete között. Ennek során az egyén egy kognitív értékelést hoz arról, hogy az adott hatás veszélyezteti-e a jóllétét, illetve, hogy az erőforrásai elegendőek-e az azzal való megküzdésre. Az elmélet két fő megküzdési stratégiát különít el: a problémafókuszú megküzdést, amely során az egyén a cselekvésre, a helyzet megváltoztatására fókuszál, valamint az érzelemközpontú megküzdést, amely elsősorban a negatív érzések csökkentésére irányul. A két fő típuson belül a megküzdési stratégiák nyolc, specifikusabb típusra oszthatóak (konfrontáció, eltávolodás, önszabályozás, társas támogatás keresése, felelősségvállalás, elkerülés-menekülés, tervezés-problémamegoldás, illetve pozitív újraértékelés; Lazarus, 1993). Az elmélet elkülönít továbbá adaptív és maladaptív megküzdési folyamatokat. Fontos megjegyezni azonban, hogy bár a megküzdési módok ezen felosztásának alkalmazása a szakirodalomban igen elterjedt, későbbi kutatásoknak nem sikerült egyértelmúen azonosítania ezeket a stratégiákat. A különböző elméletek által leírt megküzdési módokat, és a felosztásukra javasolt kategóriarendszert részletesen tárgyalják például Skinner, Edge, Altman és Sherwood (2003).

\subsection{Stressz és megküzdés - a kapcsolati dimenzió}

A klasszikus stressz modellek - köztük Lazarus és Folkman (1984) megközelítése is - a vizsgálat alapegységéül az egyént veszik, és a stresszt individuális tényezőnek tekintve ezen a szinten vizsgálják. Reiss (1981) javaslata alapján azonban az elmúlt évtizedek során kiemelkedett egy olyan nézet, amely szerint a diádikus, azaz két ember kapcsolatát érintó stressz elkülöníthető az egyént, mint individuumot érintő stressztől (Randall \& Bodenmann, 2009). Ebben a megközelítésben tehát az alapegység nem az egyén, hanem maga a kapcsolat, benne a két féllel. A megjelenő stressz ennek megfelelően nem az individuumot érinti, hanem a diádot, mint egységet, illetve a coping folyamatok is dinamikusabban, mindkét fél közremúködésével és egymásra hatásával jelennek meg. Azt könnyú belátni, hogy a stressz valóban a diádot, mint egységet érinti, ha egy "közös” a stresszorra gondolunk (mint például kommunikációs nehézségek). Azonban, ha a stresszor közvetlenül csak az egyik félre hat (mint például az egyik fél valamilyen betegsége), a hatás valamilyen mértékben a diád másik felét is érinteni fogja. Így a stressz ebben az esetben is az egész kapcsolatra hat, és a megküzdés is a diád, mint egység feladata lesz (Giunta \& Compas, 
1993). Egyes érvek szerint ez elsősorban akkor következik be, ha a stressz túl nagymértékú vagy túl hosszú időtartamú, illetve ha az elsődlegesen érintett fél nem képes az ezzel való hatékony megküzdésre (Bodenmann, 1997). A fenti megfontolások alapján alkották meg, és használják ma már egyre szélesebb körben a diádikus, azaz páros megküzdés fogalmát.

A kapcsolati megküzdés összefügg a társas támogatás jelenségével is. A stresszhelyzettel szembesülő egyének számára a megküzdés folyamatában fontos partnerük támogató magatartásának jelenléte (vö. Cutrona, Russel, \& Gardner, 2005). A megküzdési folyamat vizsgálata során a társas támogatás különböző viselkedéses formái mellett azt is érdemes figyelembe venni, hogy a másik fél ezekből a viselkedésekből mennyit érzékel, és azt hogyan interpretálja. Bizonyos esetekben az érintett fél a partnere támogatónak szánt viselkedésmódját nem értelmezi annak, ez pedig negatív hiedelmek kialakulását eredményezheti. Ez erősen hozzájárulhat a helyzet kimeneteléhez, valamint közvetetten a kapcsolat szubjektív minőségét, illetve az egészségi állapotot is befolyásolhatja (Cutrona és mtsai, 2005).

A Reiss (1981) által javasolt megközelítés, amelynek késóbbi kidolgozása és ismertté tétele főként Bodenmann (1997) nevéhez füződik, a páros megküzdést rendszerszemléletben vizsgálja, a partnerek (illetve megküzdési stratégiáik) közti dinamikus összjátékot és interakciót helyezve a fókuszba. Összefoglalónkban főként az ezen alapra épülő elméletekkel foglalkozunk. Ezek mellett azonban fontos megemlíteni, hogy a diádikus megküzdés leírására születtek olyan elméletek is, amelyek a párok individuális megküzdési módjait veszik alapul, a páros megküzdést pedig ezek additív jellegével írják le. A Revenson (1994) nyomán született „megküzdési kongruencia” (coping congruence) megközelítés eredeti feltételezése, hogy ha a párok egymáshoz hasonló megküzdési stratégiákat alkalmaznak, az hatékonyabb megküzdést és kevesebb distresszt eredményez, mint az ellentétes stratégiák használata. A kutatások azonban ezt nem igazolták: egyes kutatások nem találtak összefüggéseket ezen a téren (lásd pl. Giunta \& Compas, 1993), Pakenham (1998) eredményei továbbá épphogy azt mutatták, hogy a kimenet szempontjából előnyösek lehetnek a partnerek közti különbségek a problémafókuszú megküzdés tekintetében (míg az érzelemközpontú megküzdés esetében nem talált összefüggést).

A partnerek individuális megküzdési stratégiájának vizsgálata során fontos lehet a nemi különbségek figyelembevétele is. A kutatási eredmények arra utalnak, hogy a nők stresszhelyzetben inkább alkalmaznak érzelemközpontú megküzdési módokat: jellemzőbb rájuk az elkerülés, valamint jobban keresik, illetve igénylik a társas támogatást; ezzel szemben a férfiaknál jellemzőbben jelenik meg a problémafókuszú megküzdés (lásd pl. Matud, 2004; Ptacek, Smith, \& Dodge, 1994). Arra azonban, hogy ez a különbség a kapcsolati megküzdés dinamikáját hogyan befolyásolja, 
és esetlegesen mennyire akadályozza a párokat az adaptív közös megküzdési módok megtalálásában, a kutatások mindeddig nem adtak választ.

A diádikus megküzdést vizsgáló empirikus kutatások eredményei öszszességében arra utalnak, hogy ez a folyamat kiemelt jelentőségú a kapcsolatok életében. A közös megküzdés megjelenése erős bejóslója a kapcsolattal való elégedettségnek (Falconier, Jackson, Hilpert, \& Bodenmann, 2015; Regan és mtsai, 2014), valamint házastársak esetében a kapcsolati megküzdés sikeressége erősen összefügg a házasság szubjektív minőségével (Bodenmann, Pihet, \& Kayser, 2006). A kapcsolat megítélésén kívül a pozitív kapcsolati megküzdés alacsony mértéke, valamint a negatív megküzdés jelenléte összefüggést mutat az alacsonyabb szubjektív életminőséggel, valamint a pszichológiai kimerültséggel (Meier, Bodenmann, Mörgeli, \& Jenewein, 2011), az effektív kapcsolati megküzdés pedig a stressz agressziónövelő hatását is moderálja (Bodenmann, Meuwly, Bradbury, Gmelch, \& Ledermann, 2014). Ezek az eredmények jelzik, hogy valóban fontos a kapcsolati stressz és az erre adott válasz - azaz a diádikus megküzdés - kutatási fókuszba vétele, és külön kezelése az individuális megküzdéstől.

Az alábbiakban bemutatjuk a fogalom által leírt jelenség különböző elméleti modelljeit, és a páros megküzdési folyamatok jelentőségét. Összefoglalónk célja, hogy (1) áttekintse és összehasonlítsa a párkapcsolati stressz és megküzdés modellezésére született rendszerszemléletú elméleti megközelítéseket, (2) ismertesse az egyes megközelítések mentén, vagy ezektől függetlenül született mérési módszertanokat, illetve (3) bemutassa az elméleti keretek által nyújtott lehetőségeket a gyakorlati, terápiás alkalmazásban.

\section{A kapcsolati stressz és megküzdés leírására létrejött modellek}

\subsection{A Kapcsolatfókuszú Megküzdési Modell (KMM)}

A Kapcsolatfókuszú Megküzdési Modell (Relationship-focused Coping Model, a továbbiakban: KMM) a diádikus megküzdés fogalmában azt a folyamatot határozza meg, amikor a partnerek stressz esetén individuális erófeszítéseiken túl közös stratégiák alkalmazásában is részt vesznek a kapcsolat védelme érdekében (Coyne \& Smith, 1991). A KMM a megküzdési stratégiákat abból a szempontból írja le, ahogyan a partner a másik fél stresszére reagál, és ahogyan a helyzeten segíteni próbál.

A modellben három különböző coping stratégia jelenik meg: az aktív részvétel (active engagement), a „védő-lökhárító" hatás (protective buffering), illetve a túlvédés (overprotection). Az aktív részvétel megjelenhet olyan viselkedésekben, mint például az érzelmek megosztása, illetve 
problémamegoldás közös erőből, „védő-lökhárító” hatás lehet például az aggodalom elrejtése a partner elól, illetve a túlvédés stratégiája megnyilvánulhat például a partner megküzdési képességeinek lebecsülésében (Fiske, Coyne, \& Smith, 1991). Ezeken kívül egy negyedik lehetséges stratégia is hozzácsatolható a modellhez (Falconier és mtsai, 2015), mégpedig az O’Brien és DeLongis (1996) által leírt empatikus válasz stratégiája, amely magába foglalja a nézópontváltásra való képességet, a partner által megélt dolgok átérzését, illetve a partner stresszreakciójára való ítéletmentes, empatikus reagálást.

\subsection{A Rendszer-Tranzakciós Modell (RTM)}

A Rendszer-Tranzakciós Modell (Systemic-Transactional Model, a továbbiakban: RTM) kidolgozása Bodenmann (1997) nevéhez fúződik, aki az individuális megközelítésen túllépve egy dinamikusabb elméletet hozott létre, számításba véve a sajátos összjátékot, amely a partnerek stresszreakciójában és kapcsolati megküzdésében jelenik meg. Az elmélet szerint a diádikus stressz fogalma magába foglalja mind a direkt diádikus, azaz elsődlegesen a kapcsolatot érintő stresszt, és az indirekt diádikus, azaz elsődlegesen az egyik felet érintő stresszt. Az indirekt diádikus stressz akkor jelenik meg, amikor a stressz a nagysága vagy időtartama, illetve az érintett fél megküzdési nehézsége miatt a másik felet is érinti. Ez nemcsak akkor jöhet létre, ha az érintett fél nem képes a megküzdésre, hanem akkor is, ha a megküzdési kísérlet során az érintett fél olyan coping stratégiákat használ, amelyek nem egyeznek a partnere elvárásaival, céljaival (Bodenmann, 1997). Fontos megjegyezni, hogy Bodenmann (1997) - Lazarus és Folkman (1984) eredeti megközelítéséhez hasonlóan - a megküzdés során nem a stressz-hatás valós mértékét tekinti központi tényezőnek, hanem azt, hogy a felek ezt a hatást hogyan értékelik ki.

Bodenmann (1997) a diádikus megküzdést egy olyan folyamatként definiálja, amely elsősorban arra irányul, hogy mind az egyéni, mind a kapcsolati egyensúlyt helyreállítsa. A diádikus megküzdés során a két fél reakciói lépnek kölcsönhatásba egymással. A folyamat úgy zajlik, hogy az egyik fél verbális, vagy nonverbális formában kommunikálja a stresszreakcióját a másik fél felé, aki ezt megpróbálja dekódolni (sikeresen vagy sikertelenül), majd erre valamilyen módon reagál (vagy ignorálja azt). Ezután jöhet létre a diádikus megküzdés, amelynek módját befolyásolhatja a stressz eredete, a partnerek direkt vagy indirekt bevonódása, a két fél általános helyzete, a két fél céljai, az általános és szituációs motivációi, illetve időzítési tényezők (Bodenmann, Randall, \& Falconier, 2016). 
Az RTM nyolcféle lehetséges coping stratégiát ír le (Bodenmann, 2000; Bodenmann és mtsai, 2016). A pozitív coping stratégiák közé tartozik az érzelemközpontú-támogató diádikus megküzdés (emotion-focused supportive dyadic coping), a problémaközpontú-támogató diádikus megküzdés (problem-focused supportive dyadic coping), illetve az átruházott diádikus megküzdés (delegated dyadic coping). Érzelemközpontú-támogató megküzdési mód például segíteni a partnernek ellazulni, problémaközpontú-támogató stratégia például praktikus tanácsod adni a partnernek. Az átruházott diádikus megküzdés során az érintett fél expliciten segítséget kér, ennek nyomán pedig valamilyen segítségnyújtás jön létre - mint például bevásárlás a partner helyett, a stresszének csökkentése érdekében (Bodenmann és mtsai, 2016).

Negatív coping stratégiák az ellenséges diádikus megküzdés (hostile dyadic coping), az ambivalens diádikus megküzdés (ambivalent dyadic coping), illetve a felszínes diádikus megküzdés (superficial dyadic coping). Az ellenséges diádikus megküzdés megnyilvánulhat például a partner kigúnyolásában, az ambivalens diádikus megküzdés során a partner támogatja az érintett felet, de ezt feleslegesnek érzi, így motiválatlanul és érdektelenül vesz részt a folyamatban. A felszínes diádikus megküzdés folyamán a partner a felszínen segítókész, azonban valódi támogatást nem nyújt például a problémáról kérdezgeti a másikat, de a válaszára nem figyel (Bodenmann és mtsai, 2016).

Ezeken a pozitív, illetve negatív módokon felül megjelenhet még az együttes diádikus megküzdés stratégiája (common dyadic coping). Ezen belül elkülönül az érzelemközpontú közös megküzdés (emotion-focused common dyadic coping), illetve a problémaközpontú közös megküzdés (problem-focused common dyadic coping). Az érzelemközpontú közös megküzdés megnyilvánulhat például fizikai intimitásban, a problémaközpontú közös megküzdés pedig a probléma közös átértelmezésében. Ezek a többi stratégián olyan szempontból mutatnak túl, hogy az „egyszerü" támogatás mellett itt jelenik meg leginkább egyértelmúen mindkét fél involváltsága és együttmúködése a stressz kezelésének érdekében (Bodenmann és mtsai, 2016).

Míg az RTM eredetileg elsősorban a mindennapi kapcsolati problémákra fókuszált, késóbb alkalmazásra került a komolyabb stresszorokkal kapcsolatban is (mint az egyik fél krónikus betegsége, vagy kritikus, nagy jelentőségú életesemények), ezzel növelve a modell hatékonyságát és sokoldalúságát (Bodenmann és mtsai, 2016). Az RTM alapján végzett első kutatásokról a hazai szakirodalom is beszámolt már (Martos és mtsai, 2012; Martos, Sallay, \& Tóth-Vajna, 2016). 


\subsection{A Fejlődési-Kontextuális Modell (FKMM)}

Berg és Upchurch (2007) - Bodenmann (1997) leírásához hasonlóan diádikus megküzdésként értelmezik azokat a módokat, ahogyan a partnerek interakcióba lépnek egymással a stressz kezelése érdekében. Az általuk kidolgozott Fejlődési-Kontextuális Megküzdési Modell (DevelopmentalContextual Coping Model, a továbbiakban: FKMM) elsősorban a krónikus betegségekkel való kapcsolati megküzdés modellezésére jött létre. Az elmélet szerint a kapcsolati megküzdés a következő lépések szerint zajlik: (1) értékelés, (2) diádikus coping, (3) kiegyenlítés. Az egyes lépések mindkét partnernél lezajlanak, miközben az egyes tényezők egymással is kölcsönhatásban vannak (Berg \& Upchurch, 2007).

Az FKMM a kapcsolati megküzdést egy kontinuum mentén képzeli el, amelynek két végpontja a „nem érintett” partner teljes kívülmaradása, illetve túlinvolváltsága. A kontinuumon az egyes megküzdési módok így a „nem érintett" partner megküzdésbe való bevonódása alapján helyezkednek el (Berg \& Upchurch, 2007). Az elmélet a Berg, Meegan és Deviney (1998) által meghatározott négy kategóriát használja, mint fő megküzdési stratégiákat (de az egyéb diádikus megküzdési modellek által leírt megküzdési módokat is elhelyezhetónek tartja a kontinuumon). Ezek a fó kategóriák a kívülmaradás (uninvolvement), a támogatás (support), az együttmúködés (collaboration), illetve a kontrollálás (control). Kívülmaradásnál az érintett fél úgy érzi, hogy partnere bevonódása nélkül küzd meg a problémával, támogatás fennállása esetén a partner érzelmi vagy egyéb támogatást nyújt. Együttmúködésnél a problémamegoldásba partner is aktívan bevonódik, a kontrollálás esetében pedig a problémamegoldás során az érintett fél helyett a partnere irányít (Berg \& Upchurch, 2007).

Az FKMM különlegessége a fejlődési és a kontextuális tényezók bevonása. A modell azt feltételezi, hogy a különböző életszakaszokban eltéró coping mechanizmusok lehetnek jellemzőek (amely párhuzamban állhat a krónikus betegség különböző szakaszaival, hiszen az elmélet elsősorban az ezzel való páros megküzdés leírására jött létre). A modellben továbbá az is megjelenik, hogy a megküzdési folyamatra a kontextuális tényezők is hatással vannak, úgymint a szociokulturális kontextus (mint például a kultúra), illetve a kapcsolati kontextus (mint például a házasság szubjektív minősége; Berg \& Upchurch, 2007).

\subsection{A Kapcsolati Intimitás Modell (KIM)}

A Kapcsolati Intimitás Modell (Relationship Intimacy Model, a továbbiakban: KIM) Reis és Shaver (1988) Interperszonális Intimitás Modelljét adaptálja (Manne és mtsai, 2004). A Manne és Badr (2008) által leírt modell első- 
sorban rákos megbetegedések kapcsán vizsgálja párok megküzdését és helyzethez való alkalmazkodását. Manne és Badr (2008) szerint ennek a megértéséhez elsősorban a kapcsolatban megjelenő intimitási módokra kell fókuszálni, mint az adaptivitáshoz hozzájáruló legfontosabb mechanizmusra.

A modell három pozitív és három negatív viselkedésmódot emel ki. Pozitív stratégiaként írják le az interakciók során a kölcsönös megnyílást (reciprocal self-disclosure), a partner reakciói iránti fogékonyságot (partner responsiveness), illetve a kapcsolat mellett való elkötelezettség kimutatását (relationship engagement). A negatív stratégiák között az elkerülést (avoidance), a partnerrel szembeni kritikát (criticism), illetve a nyomásgyakorlás - kivonódást említik (pressure-withdraw). Az elkerülés megnyilvánulhat például az aggodalmak elhallgatásában, kritika lehet például a partner által alkalmazott megküzdési módok kritizálása, nyomásgyakorlás - kivonódás esetén pedig az érintett fél éppen nem szeretne egy, a betegséggel kapcsolatos problémát megvitatni, azonban partnere ragaszkodik ehhez. Az egyes viselkedésmódok építik, avagy rombolják a párkapcsolatot, így járulva hozzá a párkapcsolat intimitásszintjéhez, illetve a diádikus stresszhelyzetben létrejövő pszichológiai adaptációhoz is (Manne \& Badr, 2008).

\section{A diádikus modellek összehasonlítása}

\subsection{Stressztipológia alapján}

Az egyes elméletek nagyban különböznek abból a szempontból, hogy milyen típusú stresszfajtákat hivatottak modellezni (lásd 1. táblázat). A Kapcsolatfókuszú Megküzdési Modell viszonylag általános modell, a közvetett, párkapcsolaton kívülról jövő, és a közvetlen, kapcsolatra vonatkozó stresszt is leírja. Egyaránt foglalkozik akut és krónikus stresszfajtákkal is. Azonban nincs arra való utalás, hogy a modell nagyobb krízishelyzetekben (mint például gyógyíthatatlan betegségeknél) alkalmazásra került volna, így a stressz „komolysága” szempontjából az KMM inkább minor stresszhelyzeteket modellez. A Rendszer-Tranzakciós Modell szintén beemeli az elméletbe a közvetett és közvetlen stresszt, valamint az akut és krónikus stresszt is. Míg a modell eredetileg a mindennapi helyzetek leírására jött létre, az utóbbi években egyre inkább alkalmassá vált a komolyabb stresszt jelentő helyzetek kezelésére is. Így az RTM mára minor és major stresszorokat is leír. A Fejlódési-Kontextuális Megküzdési Modell, valamint a Kapcsolati Intimitás Modell hasonlítanak egymásra abból a szempontból, hogy mindkettő elsősorban a betegségekben érintett párokat vizsgálja. Így elsősorban ezek a modellek közvetett, krónikus és major stresszorokat írnak le. 
Ezek alapján a bemutatott modellek közül az RTM bizonyul a legsokoldalúbb elméletnek, hiszen egyaránt leírja a mindennapi bosszúságokat és a komoly stresszforrásokat is, érkezzenek akár a kapcsolaton kívülról, akár a kapcsolatból. A specifikusabb helyzetekre vonatkozó elméletek előnye lehet, hogy az adott kérdést valóban mélyrehatóan tárják fel. Azonban egy olyan elmélet, mint a KIM, amely kifejezetten csak a rákos megbetegedésekre koncentrál, túlságosan specifikus fókuszválasztásnak túnik, hiszen az elméletet valószínúleg ki lehetne terjeszteni más megbetegedésekre is, ezzel növelve alkalmazhatóságát.

1. táblázat. Az elméletek összehasonlítása az általuk modellezett stresszfajták alapján

\begin{tabular}{|l|c|c|c|}
\hline & $\begin{array}{c}\text { A stressz } \\
\text { eredete szerint }\end{array}$ & $\begin{array}{c}\text { A stressz } \\
\text { komolysága szerint }\end{array}$ & $\begin{array}{c}\text { Idóbeliség } \\
\text { szerint }\end{array}$ \\
\hline $\begin{array}{l}\text { Kapcsolatfókuszú Megküzdési } \\
\text { Modell (KMM) }\end{array}$ & $\begin{array}{c}\text { közvetett és } \\
\text { közvetlen }\end{array}$ & minor & $\begin{array}{c}\text { akut } \\
\text { és krónikus }\end{array}$ \\
\hline $\begin{array}{l}\text { Rendszer-Tranzakciós Modell } \\
\text { (RTM) }\end{array}$ & $\begin{array}{c}\text { közvetett és } \\
\text { közvetlen }\end{array}$ & minor és major & $\begin{array}{c}\text { akut } \\
\text { és krónikus }\end{array}$ \\
\hline $\begin{array}{l}\text { Fejlődési-Kontextuális } \\
\text { Megküzdési Modell (FKMM) }\end{array}$ & közvetett & major & krónikus \\
\hline $\begin{array}{l}\text { Kapcsolati Intimitás Modell } \\
\text { (KIM) }\end{array}$ & közvetett & major & krónikus \\
\hline
\end{tabular}

\subsection{A modellek által leírt megküzdési stratégiák összehasonlítása}

Mindegyik említett modell megfogalmaz különböző coping mechanizmusokat. A KMM négy, az RTM nyolc, az FKMM szintén négy, a KIM pedig hat lehetséges stratégiát ír le, ezek közül azonban néhány stratégia sok szempontból hasonlít egymásra.

A kapcsolati hatásuk szerint pozitív stratégiák két nagyobb halmazra oszthatóak, amelyeket az FKMM támogatás, illetve együttmúködés stratégiája alkot, ezek alá sorolhatóak be a többi modell pozitív stratégiái. A támogatáshoz tartozhat két, egymással párhuzamba állítható megküzdési mód, a KMM empatikus válasz stratégiája, illetve a KIM partner reakcióira való fogékonyság stratégiája. Ezen mechanizmusok során a partner érzékenysége a meghatározó. A támogatás alá sorolható továbbá a KMM aktív részvétel mechanizmusa, amely egyfajta "gyújtője” lehet az RTM problémaközpontú-támogató és érzelemközpontú-támogató stratégiájának, illetve a KIM elkötelezettség kimutatása stratégiájának. Az együttmúködés halmazába tartozhat az RTM érzelemközpontú közös és problémaközpontú közös megküzdése, illetve a KIM kölcsönös megnyílás stratégiája. 
A kapcsolati hatásuk szerint negatív stratégiák közül párhuzamba állítható az RTM ellenséges megküzdése és a KIM kritika stratégiája, míg az FKMM kívülmaradás stratégiája rokonságot mutat a KIM elkerülés stratégiájával. Az FKMM kontrolláló copingja továbbá hasonlóságot mutat a KIM nyomásgyakorlás - kivonódás stratégiájával, azzal a különbséggel, hogy az utóbbiban erőteljesebben megjelenik, hogy a domináns fél nemcsak irányít, hanem akkor is kontrollt gyakorol, ha a partnere kifejezi, hogy ezt nem szeretné.

Ezek mellett megjelent néhány olyan stratégia is, amelyek nem állíthatóak párhuzamba más megküzdési módokkal, illetve hatásuk nem egyértelmúen pozitív vagy negatív; úgymint a KMM túlvédés stratégiája, valamint az RTM átruházott, ambivalens és felszínes megküzdés módja. (Az egyes stratégiák összehasonlítását az 1. ábra szemlélteti.)

Ezen összehasonlítás alapján is az RTM túnik a legátfogóbb elméletnek, hiszen számos olyan stratégiát ír le, amelyet a többi modell is részben megfogalmazott, az RTM azonban ezeket sokszor még több lehetséges útra felbontva tárgyalja. Ezen kívül, míg a többi modell szinte minden stratégiája párhuzamba állítható más modellek stratégiáival, az RTM tartalmazza a legtöbb olyan coping mechanizmust, amely ilyen szempontból egyedi, és korábban még nem definiált.

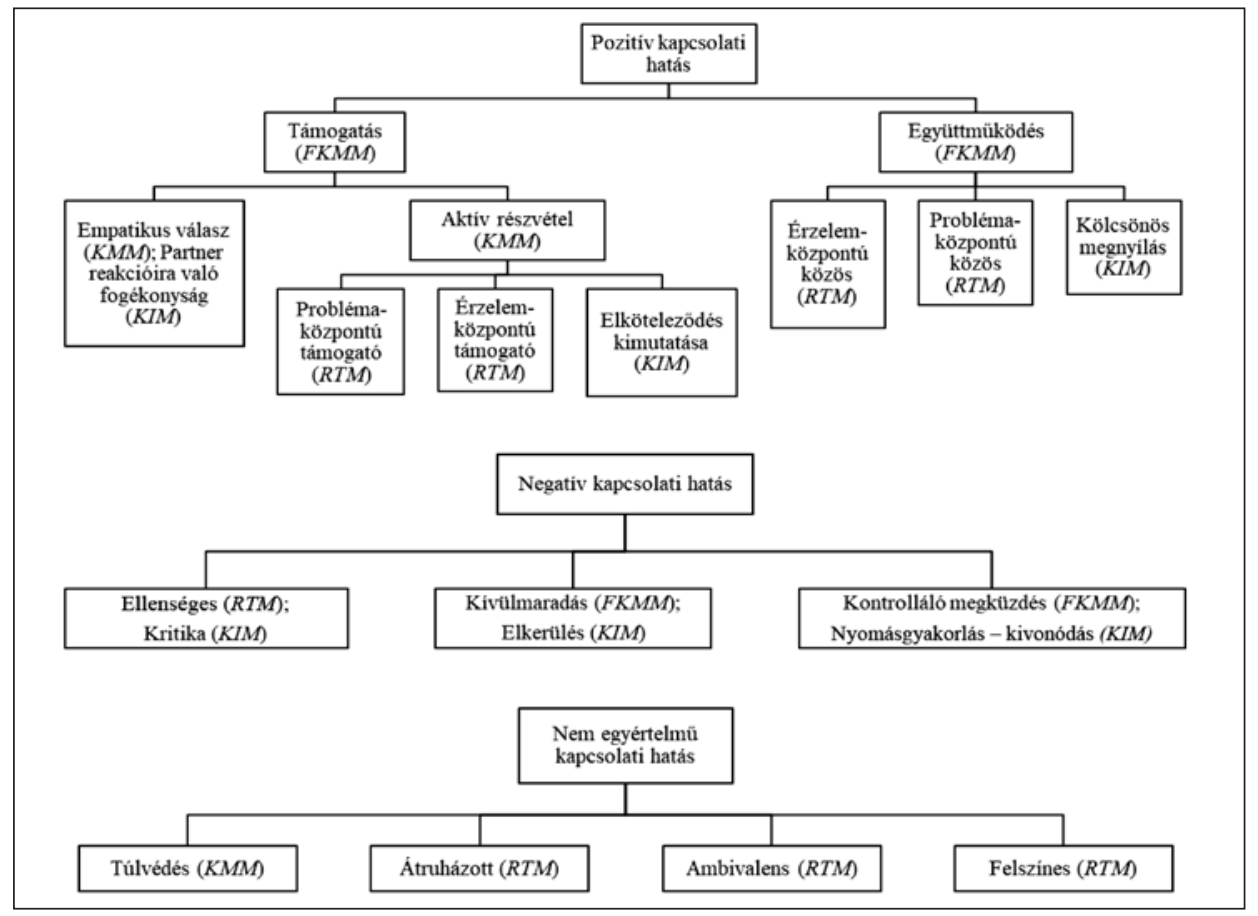

1. ábra. Az egyes megküzdési módok összehasonlítása és kapcsolati hatásuk szerinti csoportosítása 


\section{A diádikus megküzdés kutatási módszertana}

Az alábbiakban a diádikus megküzdés empirikus vizsgálatának módszereit kívánjuk bemutatni, kezdve az előzőekben bemutatott elméleti modellek alapján létrehozott méróeszközökkel, majd folytatva néhány olyan kutatási elrendezéssel, amelyek segítségével a diádikus copingot kísérleti helyzetben vizsgálták.

\subsection{Kérdőíves mérőeszközök}

A KMM modell alapján több kérdőív is létrejött. A 28 itemes RelationshipFocused Coping Scale (RFCS) eredetileg az aktív részvétel, és a „védő lökhárító" stratégiára vonatkozó tételeket tartalmazta, amelyek megjelenésének gyakoriságát a kitöltő felek egy ötfokú Likert skálán jelölték (Coyne \& Smith, 1991). Később került hozzáadásra a túlvédésre vonatkozó alskála (Fiske és mtsai, 1991). A kérdőív erőssége, hogy méri a kitöltő saját magán észlelt megküzdési mechanizmusait, illetve azokat a stratégiákat is, amelyeket ezzel egy időben a partnerén észlel, illetve használható külön az egyik fél megküzdésének vizsgálatára, és a közös kapcsolati megküzdés vizsgálatára is (Falconier és mtsai, 2015). Szintén a KMM nyomán született meg az Empathic Responding Scale (ERS), egy egyszerúbb, 10 itemes kérdőív, amely egy háromfokú Likert skálán, individuálisan méri a felek kognitív-affektív empatikus válaszát, illetve viselkedéses empatikus válaszát $\left(\mathrm{O}^{\prime}\right.$ Brien \& DeLongis, 1996).

A Dyadic Coping Inventory (DCI) az RTM alapján létrehozott kérdőív, amely Bodenmann (2000) nevéhez fúződik. A kérdőív jelenlegi legáltalánosabban alkalmazott változata 37 állítást tartalmaz, amelyek az RTM-ben meghatározott lehetséges megküzdési stratégiákra vonatkoznak, és ezek megjelenési gyakoriságát a kitöltők egy ötfokú Likert skálán értékelik (Bodenmann, 2008a; magyar változat: Martos és mtsai, 2012). A kérdőív „különlegessége”, hogy nemcsak arra kérdez rá, hogy maga a válaszadó milyen páros megküzdési módokat alkalmaz, hanem arra is, hogy a partnere részéről milyen stratégiák alkalmazását észleli. A mérőeszköz erőssége, hogy egyszerre méri a közös megküzdést, valamint a felek által a saját magukon, és a partnerükön észlelt magatartásmódokat. Ez természetesen megfelel az eredeti RTM-nek is, ami lehetővé teszi, hogy - az önkitöltős kérdőívek módszertani korlátain belül - viszonylag dinamikus képet alkothassunk a kapcsolati folyamatokról (Martos és mtsai, 2016).

Az FKMM alapján létrehozott Collaborative Coping Questionnarie (CCQ) 5 állítást tartalmaz, amelyek a partnerek (betegséghez kapcsolódó) közös megküzdési stratégiáinak alkalmazási gyakoriságára vonatkoznak, a válaszokat pedig egy ötfokú Likert skálán jelölik (Berg, Johnson, Meegan, \& 
Strough, 2003). A kérdőív specifikusan a krónikus betegséggel való közös megküzdésre vonatkozik, azonban valószínúleg adaptálható lenne mindennapi helyzetekre is, ha az állítások a betegség helyett egy konkrét, hétköznapibb problémát tartalmaznának. A kérdőív azonban elég egyoldalúan vizsgálja a megküzdést, így valószínúleg nem elég érzékeny mérőeszköz egy ilyen komplex jelenség egy gyors felmérésen túlmutató, mélyebb vizsgálatára. A CCQ ugyanis nem vizsgálja a partnerek közötti kölcsönösségeket, mint például egymás erőfeszítéseinek észlelését, egyszerúen csak individuálisan kérdez rá az egyes megküzdési stratégiák megjelenésének gyakoriságára.

\subsection{Kísérleti elrendezések}

Érdekességképpen megemlítünk két olyan kutatást, ahol a kapcsolati stresszt és megküzdést kísérleti elrendezésben vizsgálták. Bajor (2012) kutatásában főként a kommunikáció szerepét vizsgálta a párkapcsolati stressz és megküzdés kontextusában. A párok felmérése az Olson-féle Coping és stressz profil kérdőív párkapcsolatra vonatkozó alskálájának (Olson, Stewart, \& Wilson, 1991) segítségével történt. A kísérlet során a párok a Közös Rorschach Vizsgálatban (KRV; Bagdy és mtsai, 2006; Willi, 1973) vettek részt, amelynek során a pároknak közösen kellett döntenie arról, hogy az egyes Rorschach ábrák mit ábrázolnak. A helyzet így magában hordozta a stresszfaktort, és lehetőséget kínált annak megfigyelésére, hogy hogyan mutatkoznak meg a kapcsolati erőviszonyok, illetve hogyan jelennek meg az egymás támogatására, illetve a feladat közös megoldására irányuló stratégiák. Érdemes ennek alapján további kutatásokat végezni a KRV és a páros megküzdés összefüggéseinek felderítésére, mivel feltételezhető, hogy a KRV jól modellezi a kapcsolati megküzdést. Így kidolgozható a felhasználása a párterápiás munka segítésére és nyomonkövetésére is (v.ö. Vajna, 2010).

Egy másik elrendezésben Koranyi és Rothermund (2012) azt vizsgálták, hogy a párkapcsolati stressz hatására megjelenik-e egy magasabb interperszonális bizalmi szint, mint automatikus megküzdési mechanizmus. Ennek során a két felet külön szobában ültették le, és arra kérték őket, hogy képzeljenek el egy párkapcsolati stresszt indukáló szituációt (a partner egy évre való külföldre utazását). A résztvevőknek ezután bizalomjátékot ${ }^{1}$ kellett játszaniuk egy ismeretlen résztvevővel (amelynek során igazolódott a bizalmi

\footnotetext{
1 A kísérlet során a szerzők egy korábban publikált bizalomjáték módosított változatát használták - az eredeti játékot lásd Berg, Dickhaut és McCabe munkájában (1995). A játék során a résztvevők pénzegységek átutalásáról döntöttek egymás számára, attól függően, hogy mennyire bíztak a másik kooperációjában. Ha az egyik fél az utalás mellett döntött, a másik fél az összeg a többszörösét kapta kézhez, és mérlegelhette, hogy megtartja az összeget, vagy visszautal belöle (ami a másik játékoshoz szintén többszörözve jutott el).
} 
szintre vonatkozó hipotézis). A szerzők egy következő kísérletében a kísérleti csoportban lévő pároknak meg kellett nevezniük, majd maguk elé képzelniük egy olyan szituációt, amely az ő kapcsolatukban biztosan stresszt indukál (Koranyi \& Rothermund, 2012). A manipuláció után a résztvevők ismeretlen emberek arcáról készült fotókat pontoztak, szubjektív megbízhatóság szempontjából (a kísérleti csoport megnövekedett bizalmi szintje ebben az elrendezésben is megmutatkozott).

Ezen kutatások egyik, az előzőekben bemutatott elméleti keretbe sem illeszkednek közvetlen módon. Azért tartottuk fontosnak mégis megemlíteni őket összefoglalónkban, hogy hangsúlyozzuk: egy jól megválasztott kísérleti elrendezés a diádikus megküzdés vizsgálatában kiegészítheti az önbevalláson alapuló kérdőívekkel szerezhetó ismereteket. Egyúttal annak tesztelésére is szolgálhat, hogy az elméleti modellek hogyan múködhetnek a valóságos életben és hogyan alkalmazhatók leghatékonyabban a segítésben.

\section{Az elméleti modellek gyakorlati alkalmazása}

A pszichológiai gyakorlatban természetesen nem csak a helytálló, sokoldalú, valószerú modellezést nyújtó elméletek kidolgozása a cél. Miközben az elméletalkotás elhagyhatatlan része a szakmai munkának, a következő kérdés mégis az, hogy hogyan lehet felhasználni az elméleti konstrukciót a gyakorlatban, az emberek tényleges segítésére. Az alábbiakban így néhány, az előzőekben ismertetett modelleken alapuló terápiás, illetve intervenciós programot mutatunk be.

\subsection{A Párkapcsolati Megküzdéserősítő Tréning (CCET)}

Az RTM nyomán két párokat segító program is létrejött. Ezek a klasszikus kognitív viselkedésterápiák alapján múködnek, ám specifikusan a diádikus copingra és annak fejlesztésére fókuszálva (Bodenmann \& Randall, 2012). A Couple's Coping Enhancement Training (CCET) (Bodenmann, 1997), azaz Párkapcsolati Megküzdéserősítő Tréning a házastársi kompetenciák fejlesztésére szolgál (Bodenmann, 2008b). A CCET célja a stresszkezelés fejlesztése, a pár, mint egység megküzdésének fejlesztése a pozitív diádikus coping stratégiák erősítésével, és a kölcsönös érzékenység növelésével. Emellett a program tartalmaz olyan hagyományos elemeket, mint a problémamegoldó képesség fejlesztése és kommunikációt javító feladatok.

A CCET specifikus adaptációja a TOGETHER program (Falconier, 2014), amely az eredeti módszereket a párok anyagi feszültségekkel való megküzdésének fejlesztésére alkalmazza, edukációs elemekkel kiegészítve. 
A TOGETHER program alkalmai tartalmaznak egy információs blokkot és egy készségfejlesztó blokkot (egyéni, páros és csoportos feladatokkal), illetve az alkalmak közti időre a résztvevő párok házi feladatot is kapnak az elsajátított készségek gyakorlására.

\subsection{A Megküzdésorientált Párterápia (COCT)}

A Coping-Oriented Couple's Therapy (COCT), azaz Megküzdésorientált Párterápia ugyancsak az RTM-en alapul, és Bodenmann (1997) nevéhez fúződik. Szintén a kognitív viselkedésterápia talaján jött létre, és a CCET-hez hasonlóan a kommunikáció és a problémamegoldás fejlesztését szolgáló feladatokat tartalmaz (Bodenmann, 2008b). Ezeken felül a terápia fókuszában a "három fázis módszer" („three phase method") áll (Bodenmann, 2007). Ennek során a két partner a terapeuta jelenlétében oszt meg egymással stresszhez kapcsolódó érzéseket, miközben a terapeuta facilitálja a folyamatot, illetve szabályozza a megnyílás mélységét. A módszer első fázisában a „beszélö" fél megoszt egy számára stresszt okozó tényezőt, és az ezzel kapcsolatos érzéseit. A megosztott tényező először egy, a kapcsolaton kívülről származó stresszor, később pedig egy, a kapcsolatot érintő stresszor lesz. A második fázis során a másik, „hallgató" fél érzelmi támogatást igyekszik nyújtani partnerének a megosztott problémával kapcsolatban. Ez a támogatás lehet a probléma közös átértelmezése, vagy egyszerúen csak bátorítás, empátiakifejezés. A lezáró, harmadik fázis során a „beszélő" fél visszajelez a partnerének a támogatással kapcsolatban. Fontos megjegyezni, hogy ez a módszer olyan kapcsolatokra alkalmazható, ahol már van egy kialakult elköteleződés és kölcsönös tisztelet, így a „három fázis módszer” legtöbbször a terápia későbbi szakaszában kerül alkalmazásra (Bodenmann \& Randall, 2012).

\subsection{Párfókuszú intervenciók a Kapcsolati Intimitás Modell alapján}

Az Intimacy-Enhancing Couples' Therapy (IECT) (Manne \& Badr, 2008), azaz Intimitáserősítő Párterápia a KIM-en alapul. Mivel maga az elméleti modell is elsősorban azon párok vizsgálatára jött létre, ahol az egyik partner rákos megbetegedéssel küzd, így az ez alapján létrehozott terápia is specifikusan ezekre az esetekre fókuszál. Az IECT egy intervenciós programnak mondható, összesen öt (hetente egy) alkalmat foglal magába, amely az érintett pár és a terapeuta jelenlétében történik.

A program céljai közé tartozik az olyan pozitív stratégiák erősítése, mint a kölcsönös megnyílás és az egymásra való érzékenység, illetve erősen fó- 
kuszál a kapcsolatépítésre. A betegséggel kapcsolatban arra bátorítják a párokat, hogy fogalmazzák meg, mit is jelent ez az ő kapcsolatuk kontextusában, illetve hogy azonosítsák és elismerjék a betegség következtében jelentkező prioritásváltozásokat a kapcsolatukban. A pozitív stratégiák fejlesztése mellett a negatív stratégiák tetten érése is helyet kap a programban. Ebben a terapeuta folytonos visszajelzése nyújt segítséget, elkerülésére pedig a program során a kommunikációs készségek fejlesztésére koncentrálnak. A szerzők tapasztalatai alapján a program pozitív eredményeket mutatott, hatására nőttek a pozitív megküzdési stratégiák és csökkentek a negatív stratégiák, a kapcsolati intimitás nőtt, a distressz pedig csökkent (Manne \& Badr, 2008). Míg a program elsősorban a korai fázisú, mellrákos megbetegedésben érintett párokra fókuszál, a programot a célkitúzései és alkalmazott fejlesztései alapján valószínúleg a „mindennapi” párterápiába is át lehetne ültetni, bár a szerzők leírásukban erre nem utalnak.

\section{Az alkalmazás lehetséges területei}

A párkapcsolati megküzdés támogatása az élet számos területén fontos és hatékony lehet. Az alábbiakban néhány olyan területet emelünk röviden ki, ahol a párok támogatása a rendszerszerú segítés részévé is válhat, amennyiben a segítő intézmények el- és felismerik ennek fontosságát. Az egyik ilyen terület az egészségügy, konkrétabban a krónikus betegséggel élők, például rosszindulatú daganattal kezelt páciensek és partnereik segítése (Zimmermann, Baucom, Irvin, \& Heinrichs, 2015). A kutatások szerint a páciensek partnerére irányuló beavatkozások jelentős és tartós életminőség-javulást voltak képesek elérni a pár mindkét tagjában, ami nyilvánvalóan pozitív hatással lehet a kezelés sikerességére is (Heinrichs és mtsai, 2012; McLean és mtsai, 2008). Hasonlóan nagy kihívást jelentő és tartós stresszt jelentő helyzet a fogyatékos gyermek gondozása, nevelése a családban. Amint azt Topolánszky-Zsindely és Hadházi (2014) és mások is (pl. Radványi, 2013) kimutatták, a fogyatékos gyermekek szülei magukra maradnak egy olyan élethelyzetben, amelynek kihívásai sokszorosan meghaladhatják a személyes és kapcsolati erőforrásaikat. Emiatt rendszerszerú segítésük, támogatásuk alapvető feladat kellene, hogy legyen: a korai fejlesztés központjai nem csupán a gyermekek, hanem szüleik számára is biztosíthatnának kapcsolati tréninget (Topolánszky-Zsindely \& Hadházi, 2014).

Egy meglehetősen eltérő, de releváns területen, a katonai szolgálat során vállalt külföldi kiküldetés szintén szemléletes példája a párkapcsolatot érintő stressznek. A misszióval járó társas szeparáció önmagában is egy streszszel telített helyzet, ha azonban a háborús övezetet megjárt katona poszttraumás stressz tünetekkel is küzd, még súlyosabb teher nehezedhet a csa- 
ládra. A poszttraumás stresszavar (PTSD) és a párkapcsolati múködés kapcsolata sok kutatást eredményezett (lásd pl. Birkley, Eckhardt, \& Dykstra, 2016). A rendszerszemléletnek megfelelően a katonák egyéni traumatünetei bejósolták a partner párkapcsolati elégedettségét (Nelson Goff, Crow, Reisbig, \& Hamilton, 2007). Lambert, Hasbun, Engh és Holzer (2015) ezért az RTM alapján vizsgálták a veteránok poszttraumás stressz tüneteit, valamint a házastársaik által észlelt párkapcsolati minőséget. A veteránok poszttraumás tüneteinek és a párkapcsolati minőségnek a kapcsolatát jelentősen befolyásolta, hogy a házastársak mennyire érezték támogatónak a partner viselkedését stressz esetén, illetve hogy a pár mennyire érezte közös feladatnak a nehézségekkel való megküzdést. Ha a partner úgy érzékelte, hogy a katona együttmúködő és támogató, akkor a PTSD-vel járó stresszt is kisebbnek érzékelte, illetve nem érezte károsnak a párkapcsolat minőségére nézve. Az eredmények alapján elmondható, hogy az adaptív megküzdési módok, valamint a házastársi támogatás enyhíthetnek a háborús traumák okozta PTSD tünetein (Sautter, Armelie, Glynn, \& Wielt, 2011), és védőfaktorként szolgálhatnak a katonacsaládok részére (Lambert és mtsai, 2015), azonban fontos hozzátenni, hogy a PTSD ezeken felül specifikusabb kezelési módszereket is igényel.

\section{7. Összefoglalás}

A diádikus stressz és coping fogalma az utóbbi évtizedekben emelkedett ki és vált el az individuális stresszelméletektől, azt feltételezve, hogy egy szoros, intim kapcsolatban a két fél stresszét és megküzdési módjait nem lehet teljesen elválasztani egymástól, sőt, a két fél a folyamat során erős kölcsönhatásba lép egymással. A kapcsolati megküzdés rendszerszemléletú modellezésére több leírás is született, a fentiekben ezek közül négy meghatározó elméletet mutattunk be: a Kapcsolatfókuszú Megküzdési Modellt (KMM); a Rendszer-Tranzakciós Modellt (RTM); a Fejlődési-Kontextuális Megküzdési Modellt (FKMM); valamint a Kapcsolati Intimitás Modellt (KIM). Míg a KMM és az RTM általánosabb modellnek mondható, és a párkapcsolati stresszt rugalmasabb módon tudják értelmezni, az FKMM és a KIM specifikusabb elméletek, amelyek krónikus megbetegedésben érintett párok megküzdését írják le.

Az elméletek közül sok szempontból az RTM a legátfogóbb és legrugalmasabban alkalmazható modell, amely sokoldalúan használható egészen különböző kapcsolati stresszorok esetén is. Ez magyarázatot nyújt arra, hogy napjainkban miért ez a modell a legtöbbet alkalmazott a diádikus stressz és coping vizsgálatában - azonban az is igaz, hogy mindegyik bemutatott modell tartalmaz új szempontokat és olyan elemeket, amelyek ér- 
demesek a továbbgondolásra. Így az elméletalkotók következő feladata lehetne egy olyan elmélet megalkotása, amely az egyes modellek pozitívumait egyesíti, úgymint az FKMM kontextusba való beágyazottságát, az RTM dinamikus megközelítését, vagy a KIM-ben megjelenó intimitási faktor (mint adaptációt és megküzdést segító tényező) beemelését.

A bemutatott elméletek gyakorlati alkalmazására csak néhány program született. Az RTM alapján két párkapcsolati fejlesztő tréning, illetve terápia is kidolgozásra került (CCET, COCT). A KIM alapján egy intervenciós programot alakítottak ki, ez azonban kifejezetten a mellrák korai fázisában érintett párok tagjaira specializálódott. A konkrétan, explicit módon jelenlévő kapcsolati stresszorok (mint egy krónikus betegség) és az azokkal való megküzdés segítése egy viszonylag egyértelmú, jól megragadható feladat. Azonban az ilyen, specifikus módszereket valószínúleg érdemes lenne megpróbálni átültetni általános modellekbe és terápiákba, hiszen az „átlagos" párok is rendelkeznek komoly stresszforrásokkal, és ők is ugyanúgy megérdemlik a lehetőséget, hogy a megküzdési módjaikat fejlesszék.

Az élet számtalan aspektusával kapcsolatban keletkeznek nap mint nap új modellek, azonban ezek sokszor megmaradnak azon a szinten, ahonnan indultak: elméletként. Míg egy rugalmas, sokféle helyzetet modellező megközelítés egy nagyon fontos kiindulópont, és a különböző kvantitatív kutatásoknak is rendkívül sok haszna lehet, a következő kérdés, ami megfogalmazódik, az az, hogy hogyan használható fel mindez a gyakorlatban, az emberek segítésére? Az elméleti keretek továbbgondolása, és gyakorlatba való átültetése kifejezetten fontos lenne ezen a területen, ahol párkapcsolati dinamikákat vizsgálunk, és a végső cél az adaptív megküzdési módok kialakítása és fejlesztése. Így fontos célkitúzése lehet a területnek a jövőben, hogy ezek a gyakorlatban is jobban megvalósuljanak - hiszen a jól múködő elméleti modellek már rendelkezésre állnak hozzá.

\section{Irodalom}

Bagdy, E., Vetier, A., Csákvári, Zs., Kiss, D., Vargha, A., \& Bánsági, P. (2006). Processzometria. Interakciós folyamelemző eljárás a Közös Rorschach próbában. In Bagdy, E. (Szerk.): Pár-és családi kapcsolatok vizsgálata. Budapest: Bölcsész Konzorcium. Letöltve: 2017. 05. 11-én: http:/ / www.webcreator.hu/tankonyv/krv10.html

Bajor, A. (2012). A kapcsolati erőforrások szerepe a párkapcsolati kommunikációban. Alkalmazott Pszichológia, 14(4), 31-49.

Berg, C.A., Johnson, M.M.S., Meegan, S.P., \& Strough, J. (2003). Collaborative problemsolving interactions in young and old married couples. Discourse Processes, 35(1), 33-58.

Berg, C.A., Meegan, S.P., Deviney, F.P. (1998). A social-contextual model of coping with everyday problems across the lifespan. International Journal of Behavioral Development, 22(2), 239-261. 
Berg, C.A., \& Upchurch, R. (2007). A developmental-contextual model of couples coping with chronic illness across the adult life span. Psychological Bulletin, 133(6), 920-954.

Berg, J., Dickhaut, J., \& McCabe, K. (1995). Trust, reciprocity, and social history. Games and Economic Behavior, 10(1), 122-142.

Birkley, E.L., Eckhardt, C.I., \& Dykstra, R.E. (2016). Posttraumatic stress disorder symptoms, intimate partner violence, and relationship functioning: A meta-analytic review. Journal of Traumatic Stress, 29(5), 397-405.

Bodenmann, G. (1997). Dyadic coping: A systemic-transactional view of stress and coping among couples: Theory and empirical findings. European Review of Applied Psychology, 47(2), 137-141.

Bodenmann, G. (2000). Stress und Coping bei Paaren. Göttingen: Hogrefe

Bodenmann, G. (2007). Dyadic coping and the 3-phase-method in working with couples. In L. VandeCreek (Ed.), Innovations in clinical practice: Focus on group and family therapy (235-252). Sarasota: Professional Resources Press

Bodenmann, G. (2008a). Dyadisches Coping Inventar: Test manual [Dyadic Coping Inventory: Test manual]. Bern: Huber

Bodenmann, G. (2008b). Dyadic coping and the significance of this concept for prevention and therapy. Zeitschrift für Gesundheitspsychologie, 16(3), 108-111.

Bodenmann, G., Meuwly, N., Bradbury, T.N., Gmelch, S., \& Ledermann, T. (2014). Stress, anger, and verbal aggression in intimate relationships: Moderating effects of individual and dyadic coping. Journal of Social and Personal Relationships, 27(3), 408-424.

Bodenmann, G., Pihet, S., \& Kayser, K. (2006). The relationship between dyadic coping and marital quality: A 2-year longitudinal study. Journal of Family Psychology, 20(3), 485-493.

Bodenmann, G., \& Randall, A.K. (2012). Common factors in the enhancement of dyadic coping. Behavior Therapy, 43(1), 88-98.

Bodenmann, G., Randall, A.K., Falconier, M.K. (2016). Coping in couples: The Systemic Transactional Model (STM). In M.K. Falconier, A.K. Randall, \& G. Bodenmann (Eds.), Couples coping with stress: A cross-cultural perspective (5-22). New York: Routledge

Coyne, J.C., \&Smith, D.A.F. (1991). Couples coping with a myocardial infarction: A contextual perspective on wives' distress. Journal of Personality and Social Psychology, 61(3), 404-412.

Cutrona, C.E., Russell, D.W., \& Gardner, K.A. (2005). The relationship enhancement model of social support. In T.A. Revenson, K. Kayser, \& G. Bodenmann (Eds.), Couples coping with stress - Emerging perspectives on dyadic coping (73-95). Washington: American Psychological Association

Elliott, G.R., \& Eisdorfer, C. (1982). Stress and human health. New York, NY: Springer

Falconier, M.K. (2014). Together - a couples' program to improve communication, coping, and financial management skills: development and initial pilot-testing. Journal of Marital and Family Therapy, 41(2), 236-250.

Falconier, M.K., Jackson, J.B., Hilpert, P., \& Bodenmann, G. (2015). Dyadic coping and relationship satisfaction: A meta-analysis. Clinical Psychology Review, 42(1), 28-46.

Farrell, A.K., \& Simpson, J.A. (2017). Effects of relationship functioning on the biological experience of stress and physical health. Current Opinion in Psychology, 13, 49-53.

Fiske, V., Coyne, J.C., \& Smith, D.A. (1991). Couples coping with myocardial infarction: An empirical reconsideration of the role of overprotectiveness. Journal of Family Psychology, $5(1), 4-20$.

Giunta, C.T., \& Compas, B.E. (1993). Coping in marital dyads: Patterns and associations with psychological symptoms. Journal of Marriage and Family, 55(4), 1011-1017. 
Heinrichs, N., Zimmermann, T., Huber, B., Herschbach, P., Russell, D.W., \& Baucom, D.H. (2012). Cancer distress reduction with a couple-based skills training: a randomized controlled trial. Annals of Behavioral Medicine, 43(2), 239-252.

Karantzas, G.C., Simpson, J.A., \& McCabe, M.P. (2017). Editorial overview: Contemporary insights into the relationships and stress nexus: Contexts, processes and outcomes. Current Opinion in Psychology, 13, IV-VI.

Koranyi, N., \& Rothermund, K. (2012). Automatic coping mechanisms in committed relationships: Increased interpersonal trust as a response to stress. Journal of Experimental Social Psychology, 48(1), 180-185.

Lambert J.E., Hasbun, A., Engh, R., \& Holzer, J. (2015). Veteran PTSS and spouse relationship quality: The importance of dyadic coping. Psychological Trauma: Theory, Research, Practice, and Policy, 7(5), 493-499.

Lazarus, R. S. (1993). Coping theory and research: Past, present, and future. Psychosomatic Medicine, 55(3), 234-247.

Lazarus, R.S., Cohen, J.B. (1977) Environmental Stress. In I. Altman, \& J.F. Wohlwill (Eds.), Human Behavior and Environment: Advances in Theory and Research, Volume 2 (89-127). New York: Plenum Press

Lazarus, R.S., \& Folkman, S. (1984). Stress, appraisal, and coping. New York: Springer

Manne, S., \& Badr, H. (2008). Intimacy and relationship processes in couples' psychosocial adaptation to cancer. Cancer, 112(11), 2541-2555.

Manne, S., Ostroff, J., Rini, C., Fox, K., Goldstein, L., \& Gara, G. (2004). The interpersonal process model of intimacy: The role of self-disclosure, partner disclosure, and partner responsiveness in interactions between breast cancer patients and their partners. Journal of Family Psychology, 18(4), 589-599.

Martos, T., Sallay, V., Nistor, M., \& Józsa, P. (2012). Párkapcsolati megküzdés és jóllét a Páros megküzdés Kérdőív magyar változata. Psychiatria Hungarica, 27(6), 446-458.

Martos, T., Sallay, V., Tóth-Vajna, R. (2016). Dyadic coping in Hungarian couples. In M.K. Falconier, A.K. Randall, \& G.Bodenmann (Eds.), Couples coping with stress: A cross-cultural perspective (170-186). New York: Routledge

Matud, M.P. (2004). Gender differences in stress and coping styles. Personality and Individual Differences, 37(7), 1401-1415.

McEwen, B.S. (1998). Stress, adaptation, and disease: Allostasis and allostatic load. Annals of the New York Academy of Sciences, 840(1), 33-44.

McEwen, B.S. (2007). Physiology and neurobiology of stress and adaptation: central role of the brain. Physiological reviews, 87(3), 873-904.

McEwen, B.S., \& Seeman, T. (1999). Protective and damaging effects of mediators of stress: elaborating and testing the concepts of allostasis and allostatic load. Annals of the New York Academy of Sciences, 896(1), 30-47.

McLean, L.M., Jones, J.M., Rydall, A.C., Walsh, A., Esplen, M.J., Zimmermann, C., et al. (2008). A couples intervention for patients facing advanced cancer and their spouse caregivers: outcomes of a pilot study. Psycho-Oncology, 17(11), 1152-1156.

Meier, C., Bodenmann, G., Mörgeli, H., \& Jenewein, J. (2011). Dyadic coping, quality of life, and psychological distress among chronic obstructive pulmonary disease patients and their partners. International Journal of Chronic Pulmonary Disease, 6(1), 583-595.

Nelson Goff, B.S., Crow, J.R., Reisbig, A.M.J., \& Hamilton, S. (2007). The impact of individual trauma symptoms of deployed soldiers on relationship satisfaction. Journal of Family Psychology, 21(3), 344-353. 
Nussbeck, F.W., \& Jackson, J.B. (2016). Measuring dyadic coping across cultures. In M.K. Falconier, A.K. Randall, \& G.Bodenmann (Eds.), Couples Coping with Stress: A CrossCultural Perspective (36-53). New York: Routledge

O'Brien, T.B., \& DeLongis, A. (1996). The Interactional context of problem-, emotion-, and relationship-focused coping: The role of the Big Five personality factors. Journal of Personality, 64(4), 775-813.

Olson, D.H., Stewart, K.L., Wilson, L.R. (1991). Coping and Stress Profile (CSP). Minneapolis: Life Innovation

Pakenham, K.I. (1998). Couple coping and adjustment to multiple sclerosis in care receivercarer dyads. Family Relations, 47(3), 269-277.

Ptacek, J.T., Smith, R.E., \& Dodge, K.L. (1994). Gender differences in coping with stress: When stressor and appraisals do not differ. Personality and Social Psychology Bulletin, 20(4), 421-430.

Radványi, K. (2013). Legbelső kör: A család: Eltérő fejlődésü vagy krónikus beteg gyermek a családban. Budapest: ELTE Eötvös Kiadó

Randall, A.K., \& Bodenmann, G. (2009). The role of stress on close relationships and marital satisfaction. Clinical Psychology Review, 29(2), 105-115.

Regan, T.W., Lambert, S.D., Kelly, B., McElduff, P., Girgis, A., Kayser, K., et al. (2014). Cross-sectional relationships between dyadic coping and anxiety, depression, and relationship satisfaction for patients with prostate cancer and their spouses. Patient Education and Counseling, 96(1), 120-127.

Reis, H., \& Shaver, P. (1988). Intimacy as an interpersonal process. In S. Duck (Ed.), Handbook of personal relationships (367-389). Chichester: Wiley

Reiss, D. (1981). The family's construction of reality. Cambridge: Harvard University Press.

Revenson, T.A. (1994). Social support and marital coping with chronic illness. Annals of Behavioral Medicine, 16(2), 122-130.

Sautter, F.J., Armelie, A.P., Glynn, S.M., \& Wielt, D.B. (2011). The development of a couplebased treatment for PTSD in returning veterans. Professional Psychology: Research and Practice, 42(1), 63-69.

Selye, H. (1976). Forty years of stress research: principal remaining problems and misconceptions. Canadian Medical Association Journal, 115(1), 53-56.

Skinner, E.A., Edge, K., Altman, J., \& Sherwood, H. (2003). Searching for the structure of coping: A review and critique of category systems for classifying ways of coping. Psychological Bulletin, 129(2), 216-269.

Slatcher, R.B., \& Schoebi, D. (2017). Protective processes underlying the links between marital quality and physical health. Current Opinion in Psychology, 13, 148-152.

Topolánszky-Zsindely, K., \& Hadházi, É. (2014). A párkapcsolati elégedettség összefüggése a páros megküzdéssel korai fejlesztésre szoruló gyermeket (is) nevelő szülőknél. A Magyar Családterápiás Egyesület XXVIII. Vándorgyúlése, Eger, 2014. április 25-27.

Vajna, R. (2010). Párkapcsolati problémák tükrözödése terápiás kapcsolatokban és a terápia során bekövetkező változások. Szakdolgozat (BA). Budapest: Károli Gáspár Református Egyetem, Bölcsészettudományi Kar, Pszichológiai Intézet

Willi, J. (1973). Der Gemeinsame Rorschach Versuch. Diagnostikvon Paar-und Gruppenbeziehungen. Bern: Huber

Zimmermann, T., Baucom, D.H., Irvin, J.T., \& Heinrichs, N. (2015). Cross-country perspectives on social support in couples coping with breast cancer. Frontiers, 4(4), 52-61. 


\title{
Szerzói munkamegosztás
}

Martos Júlia: a cikk koncepciójának kidolgozása, szakirodalmi keresés, a kézirat megszövegezése és gondozása. Sallay Viola: a cikk koncepciójának kidolgozása, közremúködés a végleges kézirat kialakításában. Szabó Evelin: szakirodalmi keresés, közremúködés a kézirat megszövegezésében. Tóth-Vajna Rita: szakirodalmi keresés, közremúködés a kézirat megszövegezésében. Martos Tamás: a cikk koncepciójának kidolgozása, szakirodalmi keresés, közremúködés a végleges kézirat kialakításában

\section{Nyilatkozat érdekütközésről}

A szerzők ezúton kijelentik, hogy esetükben nem állnak fenn érdekütközések.

\section{Dyadic Stress and Dyadic Coping - Theoretical Models and Applications}

\author{
MARTOS, JÚLIA - SALLAY, VIOLA - SZABÓ, EVELIN - \\ TÓTH-VAJNA, RITA - MARTOS, TAMÁS
}

Beyond individually focused models of coping, social aspects of stress and coping processes gained both theoretical and practical significance in the last decades. In our review we present several models of dyadic stress and dyadic coping. Specifically, we provide descriptions of the Relationship-focused Coping Model, the Systemic-Transactional Model, the Developmental-Contextual Coping Model, and the Relationship Intimacy Model. These theoretical approaches are compared across a) the stress types they integrate into the model and b) the dyadic coping mechanisms they describe. Moreover, we provide an overview of the empirical methodologies - e.g., scales and experimental settings - that aim to investigate dyadic coping processes. We also refer to the practical and therapeutic applications of the models. In conclusion we argue that the presented models of dyadic stress and coping can be well interpreted in a broader framework of relationship science and that these models provide sufficient foundation for further applications as well.

Keywords: dyadic coping, dyadic stress, Developmental-Contextual Coping Model, Relationship-focused Coping Model, Relationship Intimacy Model, Systemic-Transactional Model 